\title{
МИКРОФЛОРА ЖЕЛУДОЧНО-КИШЕЧНОГО ТРАКТА И ПРОДУКТИВНОСТЬ ЦЫПЛЯТ-БРОЙЛЕРОВ (Gallus gallus L.) ПОД ВЛИЯНИЕМ КОРМОВЫХ ДОБАВОК ИЗ ГИДРОЛИЗАТОВ КЕРАТИН- И КОЛЛАГЕНСОДЕРЖАЩЕГО СЫРЬЯ*
}

\author{
В.И. ФИСИНИН ${ }^{1, \text { В.С. ЛУКАШЕНКО } 1 \text {, И.П. САЛЕЕВА }}{ }^{\text {, }}$ \\ Г.Ю. ЛАПТЕВ 2 , Л.А. ИЛЬИНА ${ }^{2}$ В.Г. ВОЛИК ${ }^{3}$, Д.Ю. ИСМАИЛОВА ${ }^{3}$
}

Использование новых белковых кормовых добавок животного происхождения вместо дорогостоящей рыбной муки - актуальное направление исследований в современном промышленном птицеводстве. Разработаны новые кормовые добавки из вторичного сырья, которое возникает при убое и переработке птицы. В настоящей работе мы впервые провели сравнительный анализ бактериального сообщества содержимого слепых отростков кишечника у цыплят-бройлеров (Gallus gallus L.) кросса Ross 308 при включении в рацион белковых кормовых добавок из кератин- и коллагенсодержащего сырья, полученных методом кратковременного высокотемпературного гидролиза в тонком слое. Показана возможность использования новых кормовых добавок для повышения продуктивности и качества мяса цыплят-бройлеров. Нашей целью была оценка влияния белковых кормовых добавок из кератин- и коллагенсодержащего сырья, полученных методом кратковременного высокотемпературного гидролиза в тонком слое, на микрофлору желудочно-кишечного тракта и продуктивность цыплят-бройлеров. В условиях вивария Селекционно-генетического центра «Загорское ЭПХ» (г. Сергиев Посад, Московская обл.) были проведены исследования на цыплятах-бройлерах, выращенных на подстилке с 1-суточного до 38- и 49суточного возраста. Цыплята-бройлеры I группы (контроль) получали комбикорма, в которых основным источником сырого протеина была рыбная мука. Во II группе вместо рыбной муки использовали кормовую добавку из гидролизата кератинсодержащего сырья (пера), в III группе добавку из гидролизата коллагенсодержащего сырья (отходы после обвалки тушек), в IV группе добавку из смеси гидролизатов кератин- и коллагенсодержащего сырья с включением пробиотического препарата на основе живых бактерий Bacillus subtilis, Lactobacillus paracasei, Enterococcus faecium («Бацелл-М», Россия). С помощью молекулярно-генетического анализа методом T-RFLP (terminal restriction fragment length polymorphism) определяли относительное количество и состав микроорганизмов в слепых отростках кишечника у цыплят-бройлеров. Учитывали живую массу птицы в 38- и 49-суточном возрасте (индивидуальное взвешивание), среднесуточный прирост живой массы, сохранность поголовья, затраты корма на 1 кг живой массы, сортность и массу потрошеных тушек, убойный выход мяса, мясные качества тушек, переваримость и использование питательных веществ корма. Включение в рацион цыплят-бройлеров гидролизатов кератин- и коллагенсодержащего сырья не оказывало отрицательного влияния на микрофлору желудочнокишечного тракта птицы. Содержание нормальной микрофлоры в слепых отростках кишечника было высоким во всех группах. Целлюлозолитические бактерии из класcа Clostridia филума Firmicutes (в том числе семейств Ruminococcaceae, Eubacteriaceae, Lachnospiraceae, Clostridiaceae) и филума Bacteroidetes занимали доминирующее положение в сообществе. Наиболее высокая продуктивность и качество мяса птицы были получены при использовании кормовых добавок из гидролизата кератинсодержащего сырья (II групाа), а также кормовой добавки из смеси гидролизатов кератин и коллагенсодержащего сырья с включением пробиотического препарата (IV группа). Во II группе средняя живая масса бройлеров увеличивалась в 38- и 49-суточном возрасте соответственно на 9,2 и $10,1 \%$ (р $\leq 0,01$ и p $\leq 0,001)$ по сравнению с контролем. При $100 \%$ сохранности поголовья затраты корма на 1 кг прироста живой массы были ниже контроля на 6,32 и 7,28 \%. В IV группе средняя живая масса цыплят в возрасте 38 сут повышалась на 5,30\%, затраты корма снижались на $2,87 \%$ при $100 \%$ сохранности поголовья. В 49-суточном возрасте средняя живая масса цыплят превышала контроль на 4,96 \% при затратах корма на 4,37 \% ниже, чем в I группе.

Ключевые слова: цыплята-бройлеры, кросс Ross 308, кератин- и коллагенсодержащие продукты, ферментативный гидролиз, микрофлора слепых отростков, продуктивность бройлеров, качество мяса.

Оптимальное функционирование сегментов пищеварительного тракта сельскохозяйственной птицы во многом зависит от системы питания. На микрофлору желудочно-кишечного тракта (ЖКТ) прямое воздействие оказывает структура кормов $(1,2)$. Нарушения в кормлении вызывают не-

\footnotetext{
* Работа была подготовлена при поддержке РНФ (Соглашение № 17-16-01028).
} 
желательные изменения микробиоценоза, что отрицательно сказывается на продуктивности птицы и приводит к возникновению болезней.

Первые дни жизни цыплят после вывода считаются критическими для их дальнейшего роста и развития. В этот период в организме происходит метаболический и физиологический переход от питания остаточным желтком яйца к комбикорму. Кишечник быстро развивается, чтобы эффективно усваивать питательные вещества корма. Медленное формирование кишечной микрофлоры может быть следствием неблагополучного состояния кормов, воды и условий содержания, что, в свою очередь, ставит под угрозу правильное развитие организма (3).

Содержимое ЖКТ птицы представляет собой благоприятную среду для роста многих бактерий (4). Вредные группы бактерий могут быть вовлечены в развитие инфекций и выработку токсинов. Популяции полезных бактерий участвуют в выработке витаминов, а также подавляют вредные бактериальные популяции $(5,6)$. Микрофлора метаболизирует несколько питательных веществ, которые не способен переварить организм, и превращает их в конечные продукты (например, жирные кислоты). Она не только защищает организм от экзогенных патогенов, способных колонизировать клетки и ткани, но и играет важную роль в обеспечении иммунитета. Любые изменения функций ЖКТ приводят к ухудшению всасывания и усвоения питательных веществ, увеличению секреции, развитию дисбактериоза, снижению устойчивости к заболеваниям и продуктивности птицы в целом (7).

Известно, что наибольшее скопление микроорганизмов $\left(10^{10}-10^{11} \mathrm{Ha}\right.$ 1 г содержимого) по сравнению с другими отделами ЖКТ типично для слепых отростков кишечника (8). Микрофлора, присутствующая там, играет важную роль в переваривании кормов и выполняет множественные функции по поддержанию гомеостаза макроорганизма в целом (9-12). Структура микробного сообщества слепой кишки достаточно сложна и еще полностью не охарактеризована. Преимущество микробных технологий заключается в том, что они способны улучшить понимание функций и структуры микробиоты кишечника, взаимосвязей между организмом и микробиотой, а также помогают выбирать альтернативные продукты, которые способствуют здоровью кишечника $(13,14)$. Новые молекулярные технологии дают возможность проводить детальную молекулярную и физиологическую оценку, включая количественное определение отдельных видов микроорганизмов и их метаболитов (15).

Разработанные и усовершенствованные молекулярно-генетические методы позволяют исследовать разные бактерии без ограничений. Один из эффективных подходов к определению микрофлоры - использование полимеразной цепной реакции, в частности экспресс-метода на основе ТRFLP-анализа (terminal restriction fragment length polymorphism). Он включает выделение ДНК, амплификацию целевых фрагментов и секвенирование с последующим исследованием полученных T-RFLP-грамм с привлечением баз данных с помощью программы Fragment Sorter и комплексным анализом на основе статистических (корреляционный и кластерный), таксономических и экологических подходов (16).

Использование молекулярно-генетических методов позволило значительно расширить понятия о биоразнообразии микроорганизмов в желудочно-кишечном тракте птицы. В настоящее время в ЖКТ насчитывают более 900 видов бактерий, метаногенных архей, грибов. В ряде работ дана многосторонняя характеристика микробиоты кишечника цыплят-бройлеров, которая позволила детально исследовать важные закономерности в 
функционировании этой сложной микробиоэкосистемы $(17,18)$. Кишечная микробиота цыплят-бройлеров изучается на протяжении многих лет, поскольку она неотъемлемо вовлечена во многие физиологические процессы и влияет как на питание, так и на здоровье птицы $(19,20)$. С помощью молекулярных технологий изучают механизмы действия новых кормовых добавок к рационам, оценивают изменения в кишечном микробиоме и иммунной функции. Применение таких продуктов в бройлерной промышленности необходимо для укрепления здоровья кишечника у цыплят-бройлеров и минимизации рисков (21).

В России T-RFLP-анализ используется относительно недавно, в частности в 2008 году компания ООО «Биотроф» модифицировала этот метод для изучения микрофлоры ЖКТ у сельскохозяйственной птицы. Он позволяет оценить влияние различных компонентов рациона на микробный фон и выявить взаимосвязи между его составом, структурой и показателями продуктивности птицы. Кроме того, метод перспективен для ранней диагностики бактериальных болезней. Поэтому с его помощью можно осуществить рациональный выбор кормовых добавок для (22).

В настоящей работе мы впервые провели сравнительный анализ бактериального сообщества содержимого слепых отростков кишечника у цыплят-бройлеров при включении в рацион белковых кормовых добавок из кератин- и коллагенсодержащего сырья, полученных методом кратковременного высокотемпературного гидролиза в тонком слое. Показана возможность использования новых кормовых добавок для повышения продуктивности и качества мяса у цыплят-бройлеров.

Цель наших исследований заключалась в оценке влияния белковых кормовых добавок из кератин- и коллагенсодержащего сырья, полученных методом кратковременного высокотемпературного гидролиза в тонком слое, на микрофлору желудочно-кишечного тракта и продуктивность цыплятбройлеров.

Методика. Опыты проводили в 2018 году на четырех группах цыплят-бройлеров кросcа Ross 308 (по 50 гол. в каждой), выращиваемых на подстилке в условиях вивария Селекционно-генетического центра «Загорское ЭПХ» (г. Сергиев Посад, Московская обл.) с 1-суточного возраста. Цыплята-бройлеры I группы (контроль) получали комбикорма, в которых основным источником сырого протеина была рыбная мука. Во II группе вместо рыбной муки использовали кормовую добавку из гидролизата кератинсодержащего сырья (пера), в III группе - добавку из гидролизата коллагенсодержащего сырья (отходы после обвалки тушек), в IV группе добавку из смеси гидролизатов кератин- и коллагенсодержащего сырья с включением пробиотического препарата на основе живых бактерий Bacillus subtilis, Lactobacillus paracasei, Enterococcus faecium («Бацелл-М», Россия).

При формировании опытных групп в 1-суточном возрасте цыплят индивидуально взвешивали и распределяли методом случайной выборки. Половое соотношение курочек и петушков во всех группах определяли в конце выращивания птицы. При проведении опыта цыплят подбирали по принципу аналогов - одинаковых по происхождению, возрасту, общему развитию и выведенных из одной партии яиц. Условия выращивания соответствовали технологическим нормам ФНЦ ВНИТИП РАН (23).

Учитывали живую массу бройлеров в 38- и 49-суточном возрасте (индивидуальное взвешивание), среднесуточный прирост живой массы, сохранность поголовья, затраты корма на 1 кг живой массы, сортность и массу потрошеных тушек, убойный выход мяса, мясные качества тушек, переваримость и использование питательных веществ корма в соответст- 
вии с методикой проведения физиологических (балансовых) опытов (24). Для изучения микрофлоры ЖКТ у цыплят-бройлеров в возрасте 38 и 49 сут отбирали образцы слепых отростков кишечника и методом T-RFLP исследовали содержимое.

Тотальную ДНК из образцов выделяли с помощью набора Genomic DNA Purification Kit («Fermentas, Inc.», Литва) согласно рекомендациям производителя. Выделение проводили одновременно для трех образцов из каждой опытной группы, затем образцы в каждой группе объединяли в одну пробу для дальнейшего анализа. ПЦР-амплификацию осуществляли на ДНК-амплификаторе Verity («Life Technologies, Inc.», США) с помощью эубактериальных праймеров 63F (5'-CAGGCCTAACACATGCAAGTC-3') с меткой на 5'-конце (флуорофор WellRed D4, «Beckman Coulter», США) и 1492R (5'-TACGGHTACCTTGTTACGACTT-3'), которые позволяют амплифицировать фрагмент гена 16S pРНК (позиции от 63-й до 1492-й, нумерация указана для гена $16 \mathrm{~S}$ рРНК Esherichia coli) в следующем режиме: 3 мин при $95{ }^{\circ} \mathrm{C}$ (1 цикл); 30 с при $95^{\circ} \mathrm{C}, 40$ с при $55^{\circ} \mathrm{C}, 60$ с при $72{ }^{\circ} \mathrm{C}$ (35 циклов); 5 мин при $72{ }^{\circ} \mathrm{C}$ (1 цикл). Конечную концентрацию тотальной ДНК в растворе определяли с помощью флуориметра Qubit («Invitrogen, Inc.», США) с использованием наборов Qubit dsDNA BR Assay Kit («Invitrogen, Inc.», США) согласно рекомендациям производителя.

Флуоресцентно меченные ампликоны фрагментов гена $16 \mathrm{~S}$ рPHK очищали по стандартной методике. По 30-50 нг ДНК обрабатывали рестриктазами HaeIII, HhaI и MspI, следуя рекомендации изготовителя («Fermentas», Литва), в течение 2 ч при $37^{\circ} \mathrm{C}$. Продукты рестрикции осаждали этанолом, затем добавляли 0,2 мкл маркера молекулярной массы Size Standart-600 («Beckman Coulter», США) и 10 мкл формамида Sample Loading Solution («Beckman Coulter», США). Анализ проводили с помощью CEQ 8000 («Beckman Coulter», США); погрешность прибора CEQ 8000 - не более $5 \%$. Размеры пиков и их площади вычисляли в программе Fragment Analysis («Beckman Coulter», США), на основании чего выявляли подтипы (филотипы) с принятой в исследовании погрешностью в 1 нуклеотид и оценивали их относительное содержание в микробном сообществе. Принадлежность бактерий к таксономическим группам определяли с использованием базы данных (http://mica.ibest.uidaho.edu/trflp.php).

Полученные результаты обрабатывали методом дисперсионного анализа в программе Microsoft Excel 2010. В таблицах представлены средние значения $(M)$ и стандартные ошибки средних $( \pm \mathrm{SEM})$. Достоверность различий между средними значениями исследуемых показателей оценивали с помощью $t$-критерия Стьюдента в пределах следующих уровней значимости: при $\mathrm{p} \leq 0,05 ; \mathrm{p} \leq 0,01$ и $\mathrm{p} \leq 0,001$.

Результаты. Сравнительный анализ бактериального сообщества содержимого слепых отростков кишечника у цыплят-бройлеров позволил выявить различия в составе микробиоты, связанные с периодом онтогенеза и рационом птицы. Содержание нормальной микрофлоры в слепых отростках было высоким во всех группах (табл. 1). Бактерии с целлюлозо- и амилолитическими свойствами из класcа Clostridia филума Firmicutes (в том числе семейств Ruminococcaceae, Eubacteriaceae, Lachnospiraceae, Clostridiaceae) и филума Bacteroidetes занимали доминирующее положение, что соответствуют современным представлениям о микробиоте кишечника птицы $(25,26)$. Как следует из результатов, имеющихся в базах данных GenBank (https://www.ncbi.nlm.nih.gov/genbank/), Ribosomal Database Project (http://rdp.cme.msu.edu/) и Silva (http://www.arb-silva.de/), таксономический состав ЖКТ курицы и индейки на 90 \% представлен микроорганизмами из 
1. Содержание микроорганизмов (\%) в слепых отростках кишечника у цыплят-бройлеров кросcа Ross 308 в зависимости от возраста и рациона по результатам T-RFLP-анализа ( $M \pm \mathrm{SEM}$, эксперимент в условиях вивария «Загорское ЭПХ», Московская обл.)

\begin{tabular}{|c|c|c|c|c|c|c|c|c|}
\hline \multirow{3}{*}{ Микроорганизм } & \multicolumn{8}{|c|}{ Возраст, группа $(n=50)$} \\
\hline & \multicolumn{4}{|c|}{38 сут } & \multicolumn{4}{|c|}{49 сут } \\
\hline & I (контроль) & II & III & IV & I (контроль) & II & III & IV \\
\hline \multicolumn{9}{|c|}{ Нормофлора } \\
\hline Целлюлозолитики, в том числе: & $62,49 \pm 2,89$ & $60,05 \pm 2,37$ & $59,25 \pm 1,41$ & $60,28 \pm 3,08$ & $56,82 \pm 1,36$ & $45,85 \pm 1,89^{*}$ & $54,07 \pm 1,37$ & $29,19 \pm 1,13$ \\
\hline сем. Eubacteriaceae & $13,56 \pm 0,71$ & $13,24 \pm 0,58$ & $24,79 \pm 0,94 * *$ & $11,73 \pm 0,59$ & $24,32 \pm 0,96$ & $11,31 \pm 0,51^{* *}$ & $18,32 \pm 0,48^{*}$ & $8,67 \pm 0,37^{* * *}$ \\
\hline сем. Clostridiaceae & $18,57 \pm 0,65$ & $24,8 \pm 0,97^{*}$ & $6,96 \pm 0,27 * * *$ & $12,36 \pm 0,43^{* *}$ & $13,12 \pm 0,37$ & $13,72 \pm 0,33$ & $7,27 \pm 0,26 * * *$ & $7,11 \pm 0,46 * * *$ \\
\hline сем. Lachnospiraceae & $6,08 \pm 0,28$ & $2,99 \pm 0,14^{* *}$ & $2,67 \pm 0,18 * *$ & $2,14 \pm 0,13^{* *}$ & $4,68 \pm 0,17$ & $4,28 \pm 0,14$ & $2,29 \pm 0,07 * * *$ & $2,57 \pm 0,22^{* *}$ \\
\hline сем. Ruminococcaceae & $8,62 \pm 0,32$ & $5,12 \pm 0,27^{* *}$ & $6,58 \pm 0,19^{*}$ & $12,23 \pm 0,47^{* *}$ & $0,33 \pm 0,01$ & $2,30 \pm 0,14^{* * *}$ & $10,19 \pm 0,55^{* * *}$ & $1,14 \pm 0,04^{* * *}$ \\
\hline филум Bacteroidetes & $15,66 \pm 0,48$ & $13,9 \pm 0,65$ & $18,23 \pm 0,75$ & $21,82 \pm 0,69 * *$ & $14,37 \pm 0,48$ & $14,24 \pm 0,60$ & $16,00 \pm 0,67$ & $9,70 \pm 0,30 * *$ \\
\hline Лактобациллы (Lactobacillus sp., Enterococcus sp.) & $2,56 \pm 0,08$ & $5,17 \pm 0,14^{* * *}$ & $1,54 \pm 0,05^{* *}$ & $1,24 \pm 0,01^{* * *}$ & $1,79 \pm 0,03$ & $5,69 \pm 0,27 * * *$ & $2,57 \pm 0,09 * *$ & $2,02 \pm 0,07$ \\
\hline Бациллы (Bacillus sp.) & $1,31 \pm 0,04$ & $0,74 \pm 0,03^{* *}$ & $0,79 \pm 0,01^{* *}$ & $2,60 \pm 0,09^{* * *}$ & $1,11 \pm 0,02$ & $2,23 \pm 0,06 * * *$ & $1,19 \pm 0,03$ & $11,69 \pm 0,41^{* * *}$ \\
\hline Селеномонады (Selenomonas sp., Veillonella sp.) & $8,23 \pm 0,25$ & $10,24 \pm 0,45^{*}$ & $10,78 \pm 0,38^{*}$ & $12,27 \pm 0,44^{* *}$ & $16,89 \pm 0,57$ & $10,51 \pm 0,37^{* *}$ & $13,35 \pm 0,28^{*}$ & $5,26 \pm 0,14 * * *$ \\
\hline Бифидобактерии (сем. Bifidobacteriaceae) & 0 & $0,07 \pm 0,01$ & 0 & 0 & $0,11 \pm 0,01$ & $0,16 \pm 0,01$ & $0,24 \pm 0,01$ & $0,20 \pm 0,01$ \\
\hline \multicolumn{9}{|c|}{ Условно-патогенная микрофлора } \\
\hline Актинобактерии (пор. Actinomycetales) & $1,59 \pm 0,03$ & $4,81 \pm 0,16^{* * *}$ & $3,35 \pm 0,18^{* *}$ & $2,54 \pm 0,09^{* *}$ & $5,22 \pm 0,15$ & $7,18 \pm 0,24^{* *}$ & $10,68 \pm 0,32 * * *$ & $3,16 \pm 0,07 * *$ \\
\hline Энтеробактерии (сем. Enterobacteriaceae) & $0,12 \pm 0,01$ & $3,84 \pm 0,13^{* * *}$ & $1,16 \pm 0,03^{* * *}$ & $0,50 \pm 0,01^{* * *}$ & $2,66 \pm 0,11$ & $2,28 \pm 0,09$ & $3,26 \pm 0,12 *$ & $1,92 \pm 0,08^{*}$ \\
\hline \multicolumn{9}{|c|}{ Патогенная микрофлора } \\
\hline Стафилококки (Staphylococcus sp.) & $0,23 \pm 0,01$ & $0,06 \pm 0,01^{* *}$ & $1,26 \pm 0,05^{* * *}$ & $1,13 \pm 0,03^{* * *}$ & 0 & $0,22 \pm 0,01$ & $0,35 \pm 0,01$ & $0,55 \pm 0,01$ \\
\hline Клостридии (Clostridium novyi, Clostridium perfringens) & $0,99 \pm 0,03$ & $0,11 \pm 0,01^{* * *}$ & $0,79 \pm 0,02^{*}$ & $1,51 \pm 0,04 * *$ & $0,59 \pm 0,02$ & $1,96 \pm 0,08^{* * *}$ & $1,93 \pm 0,12 * *$ & $0,19 \pm 0,01^{* * *}$ \\
\hline Пастереллы (сем. Pasterellaceae) & $0,29 \pm 0,01$ & 0 & $0,64 \pm 0,02 * * *$ & $0,15 \pm 0,01^{* *}$ & 0 & $1,43 \pm 0,06$ & $0,75 \pm 0,02$ & $1,81 \pm 0,06$ \\
\hline Фузобактерии (Fusobacterium sp.) & $1,48 \pm 0,06$ & $1,76 \pm 0,04 *$ & $7,19 \pm 0,28^{* * *}$ & $3,79 \pm 0,15^{* * *}$ & $0,10 \pm 0,01$ & $0,64 \pm 0,01^{* * *}$ & $0,10 \pm 0,01$ & $1,67 \pm 0,05^{* * *}$ \\
\hline Кампилобактерии (сем. Campylobacteriaceae) & $0,38 \pm 0,01$ & $0,41 \pm 0,01$ & $0,77 \pm 0,03 * * *$ & $0,42 \pm 0,01$ & $0,49 \pm 0,02$ & $0,74 \pm 0,01^{* *}$ & $0,48 \pm 0,02$ & $6,82 \pm 0,29 * * *$ \\
\hline Пептококки (сем. Peptococcaceae) & $0,5 \pm 0,01$ & $1,26 \pm 0,04 * * *$ & $0,89 \pm 0,03^{* *}$ & $0,78 \pm 0,02 * *$ & $0,59 \pm 0,01$ & $1,42 \pm 0,04^{* * *}$ & $1,57 \pm 0,07 * * *$ & $4,82 \pm 0,19 * * *$ \\
\hline Микоплазмы (Mycoplasma sp.) & $0,5 \pm 0,01$ & 0 & $0,05 \pm 0,01$ & 0 & 0 & $0,66 \pm 0,01$ & 0 & 0 \\
\hline \multicolumn{9}{|c|}{ Транзитная микрофлора } \\
\hline Псевдомонады (сем. Pseudomonadaceae) & $5,95 \pm 0,23$ & $4,14 \pm 0,19 * *$ & $2,09 \pm 0,05^{* * *}$ & $3,92 \pm 0,13^{* * *}$ & $1,71 \pm 0,07$ & $0,33 \pm 0,01^{* * *}$ & $0,63 \pm 0,02 * * *$ & $4,64 \pm 0,14 * * *$ \\
\hline Некультивируемые бактерии & $13,38 \pm 0,41$ & $7,34 \pm 0,28^{* *}$ & $9,47 \pm 0,38^{* *}$ & $8,87 \pm 0,35^{* *}$ & $11,92 \pm 0,41$ & $18,7 \pm 0,81^{* *}$ & $8,83 \pm 0,32 * *$ & $26,06 \pm 0,98^{* * *}$ \\
\hline
\end{tabular}


филумов Firmictes, Bacteroidetes и Proteobacteria (27). В нашем опыте у 38-суточных цыплят-бройлеров доля целлюлозолитических бактерий составляла более $59 \%$, у 49-суточной птицы в I и III группах этот показатель снижался на $10 \%$, во II группе - на $30 \%$, в IV группе - в 2 раза.

Доля целлюлозолитических бактерий семейства Lachnospiraceae у птицы, рацион которой включал гидролизат коллагенсодержащего сырья (III и IV группы), была наименьшей. Кроме того, в указанных опытных группах наименьшей оказалась представленность бактерий семейства Closridiaceae, обладающих способностью ферментировать крахмал, клетчатку и некоторые другие углеводы. Доля бактерий класса Negativicutes, утилизирующих органические кислоты в результате ферментации углеводов корма, изменилась в зависимости от возраста и группы птицы. В I группе к возрасту 49 сут относительная численность селеномонад снизилась в 2 раза ( $\mathrm{p} \leq 0,001)$, во II группе она не изменилась, в III группе - выросла на $24 \%(\mathrm{p} \leq 0,01)$, а в IV группе - снизилась в 2,3 раза $(\mathrm{p} \leq 0,001)$.

Интересные изменения отмечены в отношении облигатной микрофлоры кишечника птицы - молочнокислых бактерий родов Lactobacillus, Enterococcus и бифидобактерий рода Bifidobacterium, которые благодаря синтезу различных органических кислот и бактериоцинов способны к антагонистическому вытеснению из кишечника представителей патогенных и условно-патогенных групп (сальмонеллы, протеи, стафилококки, кишечная палочка, псевдомонады, стрептококки) $(28,29)$. Количество лактобактерий рода Lactobacillus, проявляющих существенный антагонизм в отношении патогенных видов (28), в 38-суточном возрасте в I, III и IV группах не превышало 2,5 \%. Во II группе доля лактобактерий составляла 5,17 \%. В 49-суточном возрасте наблюдалось снижение относительной численности лактобактерий в I группе в 1,5 раза $(\mathrm{p} \leq 0,01)$ и увеличение их количества во II группе на $10 \%$, в III и IV группах - на $65 \%$ (p $\leq 0,01)$.

Относительная численность бацилл в I группе с возрастом птицы не изменялась, во II группе выросла в 3 раза $(\mathrm{p} \leq 0,001)$, в III группе - в 1,5 раза $(\mathrm{p} \leq 0,01)$, в IV группе - в 4 раза $(\mathrm{p} \leq 0,001)$. Бифидобактерии (сем. Bifidobacteriaceae) в образцах содержимого слепых отростков цыплят в возрасте 38 сут практически не детектировались. К 49-м сут их доля выросла во всех группах до 0,10-0,24\%.

Условно-патогенные микроорганизмы были широко представлены в сообществе. Большинство из них традиционно связывают с развитием гастроэнтеритов (сем. Enterobacteriaceae, Pseudomonadaceae). Также высокой оказалась доля актиномицетов из порядка Actinomycetales, представители которых способны вызывать актиномикозы. Относительная численность условно-патогенных актинобактерий увеличилась с возрастом цыплят в I группе в 3,3 раза ( $\mathrm{p} \leq 0,001)$, в III - в 3 раза $(\mathrm{p} \leq 0,001)$. Доля энтеробактерий повышалась в I группе в 22 раза ( $\mathrm{p} \leq 0,001)$, в III группе - в 2,8 раза $(\mathrm{p} \leq 0,001)$, в IV группе - в 3,8 раза $(\mathrm{p} \leq 0,001)$. Во II группе отмечали снижение относительного количества энтеробактерий в 1,7 раза (p $\leq 0,01)$.

Среди бактерий, способных вызывать инфекционные заболевания, были обнаружены возбудители клостридиоза (Clostridium novyi, Clostridium perfringens), пастереллеза (сем. Pasteurellaceae, род Pasteurella, род Haетоphilus), микоплазмоза (филум Tenericutes, род Mycoplasma), некротического энтерита (филум Fusobacteria), гнойно-некротических инфекций (род Staphylococcus). Содержание большинства перечисленных микроорганизмов в сообществе кишечника птиц было минорным.

Доля стафилококков была высокой только у 38-суточной птицы в III и IV группах (более 1 \%), к возрасту 49 сут количество стафилококков 
снижалось в этих группах в 2-2,5 раза. Относительная численность патогенных клостридий оказалась высокой вне зависимости от возраста цыплят. K 49-м сут в I группе их доля снижалась в 2 раза, в IV группе - в 7,5 раза. Во II и III количество этих бактерий увеличивалось с возрастом соответственно в 18 и 2,4 раза.

Доля пастерелл была низкой в возрасте 38 сут, но к 49-м сут увеличивалась во всех группах, кроме контроля. Фузобактерии в значительном количестве присутствовали во всех исследованных группах птицы в возрасте 38 сут. К 49-м сут их относительная численность в I группе снижалась в 15 раз, во II - в 2,8 раза, в III - в 72 раза, в IV - в 2,3 раза.

Относительная численность кампилобактерий оказалась низкой во всех образцах. Большое количество этих бактерий отмечали только в возрасте 49 сут в IV группе $(6,82 \%)$, что было в 16 раз выше по сравнению с 38-ми сут. Количество пептококков было низким как к 38-м сут, так и к 49-м сут. Во II группе доля пептококков оказалась выше (более 1 \%), но не изменилась с возрастом птицы. В III и IV группах этот показатель на 38 -е сут составил менее $1 \%$, но к 49-м сут повышался соответственно до 1,57 и $4,82 \%$.

Доля микоплазм в образцах была низкой и только во II группе увеличивалась на 49-е сут до 0,66 \%. Транзитная микрофлора во всех изучаемых группах присутствовала в незначительном количестве.

Результаты наших исследований по количеству и составу микроорганизмов в слепых отростках кишечника птицы в целом согласуются с данными литературы $(30,31)$. Целлюлозолитические бактерии из класса Clostridia филума Firmicutes (в том числе семейств Ruminococcaceae, Eubacteriaceae, Lachnospiraceae, Clostridiaceae и др.) и филума Bacteroidetes занимали доминирующее положение в сообществе. При этом мы установили, что включение в рацион цыплят-бройлеров гидролизатов кератин и коллагенсодержащего сырья не оказывало отрицательного влияния на микрофлору ЖКТ птицы.

В 1-суточном возрасте живая масса цыплят составляла от 45,4 до 45,9 г. В возрасте 38 сут лучшей группой по продуктивности была II опытная, в которой цыплята получали ферментированный гидролизат пера вместо рыбной муки (табл. 2). Так, средняя живая масса цыплят, в этой группе опережала показатель в контроле на 9,20\%. Средняя масса петушков и курочек составляла соответственно 2391 и 2183 г, что было на 8,78 и 9,70 \% выше по сравнению со сверстниками из I группы (базовый рацион) при достоверной разности ( $\mathrm{p} \leq 0,01$ и $\mathrm{p} \leq 0,001)$. При $100 \%$ сохранности поголовья затраты корма на 1 кг прироста живой массы были ниже на 6,32 \%, а среднесуточный прирост выше на 9,46 \% по сравнению с контролем. Использование комбикорма с включением в него ферментированного гидролизата пера в 49-суточном возрасте способствовало увеличению средней живой массы, среднесуточного прироста цыплят-бройлеров и сохранности поголовья на 4,0\%. При этом затраты корма на 1 кг прироста живой массы были на 7,28 \% ниже по сравнению с контролем. Так, средняя живая масса петушков и курочек оказалась достоверно (p $\leq 0,001)$ выше соответственно на 9,35 и 10,89\%.

Цыплята-бройлеры, которые получали кормовую добавку из ферментированного гидролизата коллагена (III группа), существенно не отличались по продуктивности от контрольной птицы в 38-суточном возрасте. Как петушки, так и курочки по средней живой массе, среднесуточному приросту и сохранности поголовья практически не отличались от цыплят в контроле, но затраты корма в этой группе оказались ниже на 0,57 \%. В воз- 
2. Показатели продуктивности цыплят-бройлеров кросса Ross 308 в зависимости от возраста и рациона (эксперимент в условиях вивария «Загорское ЭПХ», Московская обл.)

\begin{tabular}{|c|c|c|c|c|c|c|c|c|}
\hline \multirow{3}{*}{ Показатель } & \multicolumn{8}{|c|}{ Возраст, группа $(n=50)$} \\
\hline & \multicolumn{4}{|c|}{38 сут } & \multicolumn{4}{|c|}{49 сут } \\
\hline & I (контроль) & II & III & IV & I (контроль) & II & III & IV \\
\hline \multicolumn{9}{|l|}{ Средняя живая масса, г/гол.: } \\
\hline ( $(M \pm \mathrm{SEM})$ & $2198 \pm 49,8$ & $2391 \pm 38,5^{* *}$ & $2218 \pm 53,1$ & $2296 \pm 68,8$ & $3154 \pm 70,3$ & $3449 \pm 54,0^{* * *}$ & $3161 \pm 82,4$ & $3305 \pm 92,4$ \\
\hline o $(M \pm \mathrm{SEM})$ & $1990 \pm 48,1$ & $2183 \pm 31,7^{* * *}$ & $1992 \pm 38,7$ & $2114 \pm 36,5^{*}$ & $2773 \pm 68,5$ & $3075 \pm 48,9^{* * *}$ & $2789 \pm 55,8$ & $2917 \pm 63,6$ \\
\hline Средняя арифметическая $M$ & 2094 & 2287 & 2105 & 2205 & 2964 & 3262 & 2975 & 3111 \\
\hline К контролю, \% & & $+9,2$ & $+0,52$ & $+5,3$ & & $+10,05$ & $+0,37$ & $+4,96$ \\
\hline \multicolumn{9}{|l|}{ Среднесуточный прирост, г } \\
\hline$(M \pm \mathrm{SEM})$ & $53,9 \pm 0,72$ & $59,0 \pm 0,51$ & $54,2 \pm 0,65$ & $56,8 \pm 0,53$ & $59,6 \pm 0,79$ & $65,6 \pm 0,61$ & $59,8 \pm 0,73$ & $62,6 \pm 0,63$ \\
\hline Сохранность, \% & 98 & 100 & 98 & 100 & 96 & 100 & 98 & 100 \\
\hline Затраты корма на 1 кг прироста, кг & 1,74 & 1,63 & 1,73 & 1,69 & 2,06 & 1,91 & 2,02 & 1,97 \\
\hline \multicolumn{9}{|l|}{ Масса потрошеной тушки, г } \\
\hline$(M \pm \mathrm{SEM})$ & $1514 \pm 21,5$ & $1692 \pm 16,9$ & $1526 \pm 20,9$ & $1607 \pm 22,3$ & $2167 \pm 31,68$ & $2443 \pm 23,6$ & $2181 \pm 30,7$ & $2296 \pm 25,4$ \\
\hline Убойный выход, \% & 72,3 & 74,0 & 72,5 & 72,9 & 73,1 & 74,9 & 73,3 & 73,8 \\
\hline \multicolumn{9}{|l|}{ Сортность тушек, \%: } \\
\hline 1-й сорт & 65,3 & 72,0 & 67,3 & 68,0 & 68,8 & 76,0 & 69,4 & 72,0 \\
\hline 2-й сорт & 34,7 & 28,0 & 32,7 & 32,0 & 31,2 & 24,0 & 30,6 & 28,0 \\
\hline
\end{tabular}


расте 49 сут III группа по продуктивным показателям, за исключением сохранности, не отличалась от контроля. Сохранность была выше на 2,0 \%.

Введение в рацион смеси ферментированных гидролизатов пера и коллагена с использованием пробиотического препарата (IV группа) позволило повысить продуктивные показатели бройлеров. Так, на 38-е сут средняя живая масса цыплят и среднесуточный прирост живой массы были на 5,3 и 5,4 \% выше по сравнению с аналогичными показателями в I группе. Затраты корма снизились до 2,87 \% при $100 \%$ сохранности поголовья. В 49-суточном возрасте средняя живая масса цыплят превышала контроль на 4,96 \%, при этом живая масса петушков была больше на 4,79, а курочек - на 5,19\%. Среднесуточный прирост цыплят на 49-е сут в IV группе составил 62,6 г, на 5,03\% превысив контроль. Конверсия корма оказалась выше, чем в I группе, на 4,37 \%.

3. Переваримость и использование питательных веществ комбикорма (\%) цыплятами-бройлерами кросса Ross 308 в зависимости от возраста и рациона (эксперимент в условиях вивария «Загорское ЭПХ», Московская обл.)

\begin{tabular}{|c|c|c|c|c|c|c|c|c|}
\hline \multirow{3}{*}{ Показатель } & \multicolumn{8}{|c|}{ Возраст, группа $(n=3)$} \\
\hline & \multicolumn{4}{|c|}{38 сут } & \multicolumn{4}{|c|}{49 сут } \\
\hline & I (контроль) & II & III & IV & I (контроль) & II & III & IV \\
\hline \multicolumn{9}{|l|}{ Переваримость: } \\
\hline сухого вешества & 74,8 & 76,0 & 75,1 & 76,2 & 74,3 & 75,3 & 74,8 & 75,8 \\
\hline протеина & 91,1 & 93,2 & 92,5 & 93,4 & 90,2 & 92,1 & 91,4 & 92,4 \\
\hline жира & 80,5 & 83,0 & 81,2 & 83,5 & 79,8 & 82,4 & 81,6 & 83,0 \\
\hline клетчатки & 10,0 & 12,8 & 11,9 & 13,1 & 11,4 & 13,5 & 12,5 & 13,1 \\
\hline \multicolumn{9}{|l|}{ Использование: } \\
\hline азота & 57,9 & 59,4 & 58,3 & 59,9 & 56,4 & 58,5 & 57,1 & 59,1 \\
\hline кальция & 46,5 & 47,1 & 46,8 & 47,0 & 44,1 & 46,2 & 45,4 & 46,1 \\
\hline фосфора & 29,6 & 31,4 & 30,3 & 31,6 & 30,8 & 33,0 & 32,4 & 33,2 \\
\hline
\end{tabular}

Включение в комбикорм гидролизата кератинсодержащего сырья (II группа) обеспечило повышение переваримости и использования питательных веществ корма по сравнению с контролем (табл. 3). Переваримость сухого вещества у цыплят в возрасте 38 и 49 сут увеличилась на 1,2 и $1,0 \%$, протеина - на 2,1 и $1,9 \%$, жира - на 2,5 и 2,6 \%, клетчатки на 2,8 и 2,1\%. Использование азота повысилось на 1,5 и 2,1 \%, кальция на 0,6 и 2,1\%, фосфора - на 1,8 и 2,2\%.

B IV группе у птицы в 38- и 49-суточном возрасте также повысилась переваримость сухого вещества корма на 1,4 и 1,5\%, протеина - на 2,3 и 2,2 \%, жира - на 3,0 и 3,2 \% и клетчатки - на 3,1 и $1,7 \%$. Использование азота увеличилось на 2,0 и 2,7 \%, кальция - на 0,5 и 2,0 \%, фосфора - на 2,0 и 2,4 \%. Несколько ниже были показатели усвоения питательных веществ корма в III группе. Так, по сравнению с контролем переваримость сухого вещества корма здесь повысилась на 0,3 и 1,0 \% протеина - на 1,4 и 2,0 \%, жира - на 0,7 и 1,8 \% и клетчатки - на 1,9 и 1,1\%. В 38-суточном возрасте по использованию азота, кальция и фосфора значимых различий с контролем не наблюдалось и только на 49-е сут эти показатели повысились соответственно на 0,$7 ; 1,3 ; 1,6 \%$.

Для оценки мясных качеств цыплят-бройлеров проводили анатомическую разделку тушек птицы. Было установлено, что в 38-суточном возрасте в тушках бройлеров из II группы наблюдался самый высокий выход наиболее ценной части - грудных мышц (33,17 \% от массы потрошеной тушки), что было на 1,28 \% выше, чем в контроле. В целом, выход всех мышц в тушках бройлеров оказался на 1,56 \% выше по сравнению с I группой. Наибольший выход съедобных частей в тушках цыплят был получен во II группе - 79,14 \% против 77,47 \% в контроле. Это произошло в 
основном за счет более высокого (на 1,56 \%) выхода мышц в тушках бройлеров. По содержанию кожи с подкожным жиром и костей тушки бройлеров во II группе не отличались от контроля. В возрасте 49 сут выход грудных мышц был на $0,55 \%$ больше, чем в контроле. Общий выход мышц в тушках бройлеров во II группе оказался на 1,45 \%, выход съедобных частей - на 1,32 \% выше, а костной массы - на 1,22 \% ниже по сравнению с контролем.

B III группе значительных различий по мясным качествам тушек по сравнению с I группой не отмечали. B IV группе выход грудных мышц в тушках был на 0,45 и 0,46 \% выше по сравнению с контролем соответственно в 38- и 49-суточном возрасте. Выход всех мышц в тушках бройлеров превышал контроль на 0,77 и $0,97 \%$. Также в IV группе наблюдался больший выход съедобных частей в тушках в возрасте 38 и 49 сут - соответственно 78,09 и 79,76 \%, или на 0,62 \% и 0,96 \% выше контрольных значений. Различий по содержанию кожи с подкожным жиром и костей в тушках бройлеров не установили.

Самые высокие вкусовые и ароматические достоинства бульона и мяса по 5-балльной шкале были получены в II и IV группах. То есть включение в рацион цыплят-бройлеров белковых кормовых добавок из кератин- и коллагенсодержащего сырья способствовало повышению мясных и вкусовых качеств тушек цыплят-бройлеров.

Полученные в нашем исследовании результаты, в целом соответствуют современным представлениям о микробиоте слепых отростков кишечника птицы. Так, ранее сообщалось о влиянии различных кормовых компонентов рациона птицы на микрофлору кишечника (32-34), а также о возможной взаимосвязи между численностью и видовым составом микроорганизмов кишечника и продуктивностью птицы (35-37). Например, имеются сведения, что увеличение в рационах бройлеров количества ячменя, богатого некрахмалистыми полисахаридами, модифицирует микробиоценоз кишечника по видовому составу и структуре. При этом меняется видовой состав как полезных бактерий, так и патогенов, что отражается на основных зоотехнических показателях выращивания птицы и использовании питательных веществ комбикорма (38). Также сообщалось о том, что замена даже одного белкового компонента в рационе птицы оказывает заметное влияние на структуру и численность микробиоценоза кишечника бройлеров (39). Однако данные о влиянии белковых кормовых добавок из кератин- и коллагенсодержащего сырья, полученных методом кратковременного высокотемпературного гидролиза в тонком слое, на микрофлору желудочно-кишечного тракта и продуктивность цыплят-бройлеров до настоящего времени отсутствовали.

Таким образом, включение в рацион цыплят-бройлеров гидролизатов кератин и коллагенсодержащего сырья не оказывает отрицательного влияния на микрофлору желудочно-кишечного тракта. Содержание нормальной микрофлоры в слепых отростках кишечника остается высоким во всех группах. Целлюлозолитические бактерии из класcа Clostridia филума Firmicutes (в том числе семейств Ruminococcaceae, Eubacteriaceae, Lachnospiraceae, Clostridiaceae) и филума Bacteroidetes доминируют в сообществе. Кормовые добавки из гидролизата кератинсодержащего сырья, а также из смеси гидролизатов кератин- и коллагенсодержащего сырья с включением пробиотического препарата обеспечивают более высокие показатели продуктивности и качества мяса птицы. Так, в первом случае живая масса бройлеров увеличилась по сравнению с контролем на 9,2 \% (p $\leq 0,01) \mathrm{K}$ 38 -м сут и на $10,1 \%$ ( $\leq 50,001)$ к 49-м сут, а во втором соответствующие 

ности поголовья и снижении затрат корма на 1 кг прироста живой массы.

\author{
1 ФНЦ Всероссийский научно-исследовательский \\ и технологический институт птицеводства РАН, \\ 141311 Россия, Московская обл., г. Сергиев Посад, ул. Птицеградская, 10, \\ e-mail: fisinin@land.ru, lukashenko@vnitip.ru $₫$, saleeva@vnitip.ru; \\ 2000 «Биотроф+», \\ 192284 Россия, г. Санкт-Петербург, Загребский бульвар, 19, корп. 1, \\ e-mail: laptev@biotrof.ru, ilina@biotrof.ru; \\ ${ }^{3}$ Всероссийский НИИ птицеперерабатывающей \\ промышленности - филиал ФНЦ Всероссийский \\ научно-исследовательский и технологический \\ институт птицеводства РАН, \\ 141552 Россия, Московская обл., Солнечногорский р-н, \\ п/о Ржавки, ВНИИПП, \\ e-mail: volik@dinfo.ru, dilaramis08@mail.ru
}

Поступила в редакцию

Sel'skokhozyaistvennaya biologiya [Agricultural Biology], 2019, V. 54, № 2, pp. 291-303

\title{
THE EFFECTS OF FEED ADDITIVES BASED ON THE HYDROLYSATES OF KERATIN- AND COLLAGEN-CONTAINING WASTE MATERIALS ON THE INTESTINAL MICROBIOTA AND PRODUCTIVITY PARAMETERS IN BROILER CHICKS (Gallus gallus L.)
}

\author{
V.I. Fisinin', V.S. Lukashenko', I.P. Saleeva1, G.Yu. Laptev², L.A. Ilina' ${ }^{2}$, V.G. Volik³, \\ D.Yu. Ismailova ${ }^{3}$
}

\begin{abstract}
${ }^{1}$ Federal Scientific Center All-Russian Research and Technological Poultry Institute RAS, 10, ul. Ptitsegradskaya, Sergiev Posad, Moscow Province, 141311 Russia, e-mail fisinin@land.ru, lukashenko@vnitip.ru ( $\square$ corresponding author), saleeva@vnitip.ru;

${ }^{2} J S C$ «Biotrof+», 19 korp. 1, Zagrebskii bulv., St. Petersburg, 192284 Russia, e-mail laptev@biotrof.ru, ilina@biotrof.ru; ${ }^{3}$ All-Russian Research Institute of Poultry Processing Industry - Branch of Federal Scientific Center All-Russian Research and Technological Poultry Institute RAS, 1, Rzhavki, Solnechnogorsk Region, Moscow Province, 141552, e-mailvolik@dinfo.ru,dilaramis08@mail.ru ORCID:

Fisinin V.I. orcid.org/0000-0003-0081-6336 Lukashenko V.S. orcid.org/0000-0002-0107-8235

Saleeva I.P. orcid.org/0000-0002-7446-1593

Laptev G.Yu. orcid.org/0000-0002-8795-6659

The authors declare no conflict of interests

Acknowledgements:

Supported financially by Russian Science Foundation (agreement № 17-16-01028)

Received December 3, 2018

Ilina L.A. orcid.org/0000-0003-2789-4844

Volik V.G. orcid.org/0000-0002-1798-2093

Ismailova D.Yu. orcid.org/0000-0003-3918-8752
\end{abstract}

\begin{abstract}
The use of new animal-derived protein ingredients in commercial diets for poultry as a substitute for the expensive fishmeal is an urgent direction of the nutritional research. At present a range of new additives is designed based on the wastes of poultry slaughter and processing. In this paper, we first report the results of comparative analysis of the bacterial community in blind processes of the intestines of broiler chickens fed with dietary protein-rich additives derived from keratinand collagen-containing waste products after short-term high-temperature enzymatic hydrolysis in a thin layer. These findings show possibility of using new feed additives to increase the productivity and quality of broiler meat. Our study was aimed at the evaluation of the effects of the feed additives based on keratin- and collagen-containing wastes on the intestinal microbiota counts and composition in conjunction with productive performance of broiler chicks. The chicks (Gallus gallus L.) of Ross 308 cross were reared at the Vivarium of All-Russian Research and Technological Institute of Poultry (Moscow Province) on the floor until 38 or 49 days of age. Control Treatment (Trt) 1 was fed standard diet with fishmeal as the main protein source. In the diet for Trt 2 the fishmeal was substituted by a hydrolysate of keratin-containing wastes (poultry feathers); in Trt 3 by a hydrolysate of collagen-containing wastes of poultry deboning; in Trt 4 by a mixture of these additives with additional supplementation with probiotic Bacell-M (containing Bacillus subtilis, Lactobacillus paracasei, Enterococcus faecium). The counts and composition of cecal microbiota in broilers were determined using Terminal Restriction Fragment Length Polymorphism (T-RFLP) technique. The live weight at 38 and 49 days of age (individual weighing), average daily weight gain, livestock safety, feed costs per $1 \mathrm{~kg}$ of live weight, grade and weight of gutted carcasses, meat yield of carcasses and meat qualities, digestibility and use nutrient feed were recorded. The protein additives based on the hydrolysates of
\end{abstract}


poultry wastes do not compromise the composition of cecal microbiota in broilers, and the obligate species were abundant with all diets studied. Cellulolytic Clostridia class (phylum Firmicutes) including families Ruminococcaceae, Eubacteriaceae, Lachnospiraceae, Clostridiaceae etc. dominated in the cecal microbial communities. The additives beneficially affected the productive performance in broilers. The best productivity parameters were in broilers fed diets with the hydrolysate of keratincontaining material (Trt 2) and a mixture of the hydrolysates of keratin- and collagen-containing wastes with the probiotic (Trt 4). Average live bodyweight at 38 and 49 days of age in Trt 2 was significantly higher, by $9.2 \%(\mathrm{p}<0.01)$ and $10.1 \%(\mathrm{p}<0.001)$, respectively, as compared to control Trt 1. Mortality level in Trt 2 was $0 \%$ while feed conversion ratio (FCR) at 38 and 49 days of age was 6.32 and $7.28 \%$ better compared to control. Average live bodyweight in Trt 4 at 38 days of age was $5.3 \%$ higher, and FCR was $2.87 \%$ better compared to control; at 49 days of age these parameters were better in compare to control by 4.96 and $4.37 \%$, respectively, while mortality in Trt 4 during 38 and 49 days of rearing was $0 \%$.

Keywords: broiler chicks, Ross 308 cross, keratin- and collagen-containing materials, enzymatic hydrolysis, cecal microbiota, productive performance, meat quality.

\section{REFEREN CES}

1. Mateos G.G., Lázaro R.M., Gracia I. Feasibility of using nutritional modifications to replace drugs in poultry feeds. The Journal of Applied Poultry Research, 2002, 11(4): 437-452 (doi: 10.1093/japr/11.4.437).

2. Birger S. Function of the digestive system. The Journal of Applied Poultry Research, 2014, 23(2): 306-314 (doi: 10.3382/japr.2014-00937).

3. Pervova A. [Effects of probiotics in commercial poultry]. Sel'skokhozyaistvennaya Biologiya [Agricultural Biology], 2003, 4: 24-28 (in Russ.).

4. Rehman H.U., Vahjen W., Awad W.A., Zentek J. Indigenous bacteria and bacterial metabolic products in the gastrointestinal tract of broiler chickens. Archives of Animal Nutrition, 2007, 61(5): 319-335 (doi: 10.1080/17450390701556817).

5. Koutsos E.A., Arias V.J. Intestinal ecology: Interactions among the gastrointestinal tract, nutrition, and the microflora. The Journal of Applied Poultry Research, 2006, 15(1): 161-173 (doi: 10.1093/japr/15.1.161).

6. Tellez G., Higgins S.E., Donoghue A.M., Hargis B.M. Digestive physiology and the role of microorganisms. The Journal of Applied Poultry Research, 2006, 15(1): 136-144 (doi: 10.1093/japr/15.1.136).

7. Fisinin V.I., Surai P. Gut immunity in birds: facts and reflections (review). Sel'skokhozyaistvennaya Biologiya [Agricultural Biology], 2013, 4: 3-25 (doi: 10.15389/agrobiology.2013.4.3eng) (in Engl.).

8. Kohl K.D. Diversity and function of the avian gut microbiota. J. Comp. Physiol. B, 2012, 182(5): 591-602 (doi: 10.1007/s00360-012-0645-Z).

9. Zhu X.Y., Zhong T., Pandya Y., Joerger R.D. 16S rRNA-bassed analysis of microbiota from the cecum of broiler chickens. Appl. Environ. Microbiol., 2002, 68(1): 124-137 (doi: 10.1128/AEM.68.1.124-137.2002).

10. Amit-Romach E., Sklan D., Uni Z. Microflora ecology of the chicken intestine using 16S ribosomal DNA primers. Poultry Science, 2004, 83(7): 1093-1098 (doi: 10.1093/ps/83.7.1093).

11. Owens B., Tucker L., Collins M.A., McCracken K.J. Effects of different feed additives alone or in combination on broiler performance, gut microflora and ileal histology. British Poultry Science, 2008, 49(2): 202-212 (doi: 10.1080/00071660802004890).

12. Hold G.L., Schwiertz A., Aminov R.I., Blaut M., Flint H.J. Oligonucleotide probes that detect quantitatively significant groups of butyrate-producing bacteria in human feces. Appl. Environ. Microbiol., 2003, 69: 4320-4324 (doi: 10.1128/AEM.69.7.4320-4324.2003).

13. Stanley D., Denman S.E., Hughes R.J., Geier M.S., Crowley T.M., Chen H., Haring V.R., Moore R.J. Intestinal microbiota associated with differential feed conversion efficiency in chickens. Appl. Microbiol. Biotechnol., 2012, 96(5): 1361-1369 (doi: 10.1007/s00253-011-3847-5).

14. Stanley D., Hughes R.J., Moore R.J. Microbiota of the chicken gastrointestinal tract: influence on health, productivity and disease. Appl. Microbiol. Biotechnol., 2014, 98(10): 4301-4310 (doi: 10.1007/s00253-014-5646-2).

15. Gaggìa F., Mattarelli P., Biavati B. Probiotics and prebiotics in animal feeding for safe food production. International Journal of Food Microbiology, 2010, 141: S15-S28 (doi: 10.1016/j.ijfoodmicro.2010.02.031).

16. Laptev G., Nikonov I., Kryazhevskikh L., Egorov I. Ptitsevodstvo, 2010, 9: 25 (in Russ.).

17. Oakley B.B., Lillehoj H.S., Kogut M.H., Kim W.K., Maurer J.J., Pedroso A., Lee M.D., Collett S.R., Johnson T.J., Cox N.A. The chicken gastrointestinal microbiome. FEMS Microbiology Letters, 2014, 360(2): 100-112 (doi: 10.1111/1574-6968.12608).

18. Apajalahti J. Comparative gut microflora, metabolic challenges, and potential opportunities. The Journal of Applied Poultry Research, 2005, 14(2): 444-453 (doi: 10.1093/japr/14.2.444). 
19. Rinttilä T., Apajalahti J. Intestinal microbiota and metabolites-Implications for broiler chicken health and performance. The Journal of Applied Poultry Research, 2013, 22(3): 647-658 (doi: 10.3382/japr.2013-00742).

20. Kogut M.H. The gut microbiota and host innate immunity: regulators of host metabolism and metabolic diseases in poultry? The Journal of Applied Poultry Research, 2013, 22(3): 637-646 (doi: 10.3382/japr.2013-00741).

21. Roberts T., Wilson J., Guthrie A., Cookson K., Vancraeynest D., Schaeffer J., Moody R., Clark S. New issues and science in broiler chicken intestinal health: emerging technology and alternative interventions. The Journal of Applied Poultry Research, 2015, 24(2): 257-266 (doi: 10.3382/japr/pfv023).

22. Laptev G. Materialy XVII Mezhdunarodnoi konferentsii (VNAP) «Innovatsionnye razrabotki $i$ ikh osvoenie v promyshlennom ptitsevodstve» [Proc. XVII Int. Conf. «Innovations and their use in industrial poultry farming»]. Sergiev Posad, 2012: 212-215 (in Russ.).

23. Metodicheskie rekomendatsii po tekhnologii proizvodstva myasa broilerov /Pod redaktsiei V.I. Fisinina, T.A. Stollyara, V.S. Lukashenko [Guidelines for broiler meat production technology. V.I. Fisinin, T.A. Stollyar, V.S. Lukashenko (eds.)]. Sergiev Posad, 2008 (in Russ.).

24. Metodika provedeniya nauchnykh i proizvodstvennykh issledovanii po kormleniyu sel'skokhozyaistvennoi ptitsy. Molekulyarno-geneticheskie metody opredeleniya mikroflory kishechnika /Pod redaktsiei V.I. Fisinina [Methods of original research and farm trials of poultry feeding. Molecular genetic methods for intestinal microflora survey. V.I. Fisinin (ed.)]. Sergiev Posad, 2013 (in Russ.).

25. Lee K.C., Kil D.Y., Sul W.J. Cecal microbiome divergence of broiler chickens by sex and body weight. J. Microbiol., 2017, 55(12): 939-945 (doi: 10.1007/s12275-017-7202-0).

26. Broom L.J., Kogut M.H. The role of the gut microbiome in shaping the immune system of chickens. Veterinary Immunology and Immunopathology, 2018, 204: 44-51 (doi: 10.1016/j.vetimm.2018.10.002).

27. Wei S., Morrison M., Yu Z. Bacterial census of poultry intestinal microbiome. Poultry Science, 2013, 92(3): 671-683 (doi: 10.3382/ps.2012-02822).

28. Gaspar C., Donders G.G., Palmeira-de-Oliveira R., Queiroz J.A., Tomaz C., Martinez-deOliveira J., Palmeira-de-Oliveira A. Bacteriocin production of the probiotic Lactobacillus acidophilus KS400. AMB Express, 2018, 8(1): 153 (doi: 10.1186/s13568-018-0679-z).

29. Nanjundan J., Ramasamy R., Uthandi S., Ponnusamy M. Antimicrobial activity and spectroscopic characterization of surfactin class of lipopeptides from Bacillus amyloliquefaciens SR1. Microbial Pathogenesis, 2019, 128: 374-380 (doi: 10.1016/j.micpath.2019.01.037).

30. Torok V.A., Hughes R.J., Mikkelsen L.L., Perez-Maldonado R., Balding K., MacAlpine R., Percy N.J., Ophel-Keller K. Identification and characterization of potential performancerelated gut microbiota in broiler chickens across various feeding trials. Appl. Environ. Microbiol., 2011, 77(17): 5868-5878 (doi: 10.1128/AEM.00165-11).

31. Witzig M., Camarinha-Silva A., Green-Engert R., Hoelzle K., Zeller E., Seifert J., Hoelzle L.E., Rodehutscord M. Correction: spatial variation of the gut microbiota in broiler chickens as affected by dietary available phosphorus and assessed by T-RFLP analysis and 454 pyrosequencing. PLoS ONE, 2015, 10(12): e0145588 (doi: 10.1371/journal.pone.0145588).

32. Fisinin V., Egorov I., Egorova T., Lenkova T., Manukyan V., Grozina A., Laptev G., Novikova N., Il'ina L., Iyldyrym E., Nikonov I., Fillipova V., Dubrovin A. Kombikorma, 2016, 12: 94-96 (in Russ.).

33. Salaheen S., Kim S.-W., Haley B.J., Van Kessel J.A.S., Biswas D. Alternative growth promoters modulate broiler gut microbiome and enhance body weight gain. Front. Microbiol., 2017, 8: 2088 (doi: 10.3389/fmicb.2017.02088).

34. Mesa D., Lammel D.R., Balsanelli E., Sena C., Noseda M.D., Caron L.F., Cruz L.M., Pedrosa F.O., Souza E.M. Cecal microbiota in broilers fed with prebiotics. Front. Genet., 2017, 8: 153 (doi: 10.3389/fgene.2017.00153).

35. Fisinin V.I., Egorov I.A., Manukyan V.A., Laptev G.Yu., Nikonov I.N., Il'ina L.A., Novikova N.I. Ptitsa i ptitseprodukty, 2014, 6: 37-39 (in Russ.).

36. Rubio L.A. Possibilities of early life programming in broiler chickens via intestinal microbiota modulation. Poultry Science, 2019, 98(2): 695-706 (doi: 10.3382/ps/pey416).

37. Jankowski J., Juskiewicz J., Gulewicz K., Lecewicz A., Slominski B.A., Zdunczyk Z. The effect of diets containing soybean meal, soybean protein concentrate, and soybean protein isolate of different oligosaccharide content on growth performance and gut function of young turkeys. Poultry Science, 2009, 88: 2132-2140 (doi: 10.3382/ps.2009-00066).

38. Iyldyrym E.A., Il'ina L.A., Nikonov I.N., Novikova N.I., Laptev G.Yu., Manukyan V.A., Egorov I.A. Ptitsa i ptitseprodukty, 2014, 3: 40-42 (in Russ.).

39. Laptev G.Yu., Novikova N.I., Nikonov I.N., Il'ina L.A., Iyldyrym E.A., Filippova V.A., Brazhnik E.A., Egorov I.A., Egorova T.V. Zootekhniya, 2014, 12: 29-30 (in Russ.). 